\title{
Growth and Structural Development of Tectona grandis in Different Cultivation Systems in Brazil
}

\author{
Reginaldo A. Medeiros ${ }^{1}$, Carlos A. R. Domiciano ${ }^{1}$, Vitor Leseux ${ }^{1}$, Alvaro A. V. Soares ${ }^{2}$, \\ Antonio A. Tsukamoto Filho ${ }^{3}$, Fulvianny C. Silva ${ }^{1} \&$ Helio G. Leite ${ }^{4}$ \\ ${ }^{1}$ Federal Insitute of Mato Grosso, Campus Cáceres-Prof. Olegario Baldo, Mato Grosso, Brazil \\ ${ }^{2}$ Federal University of Uberlandia, Minas Gerais, Brazil \\ ${ }^{3}$ Federal University of Mato Grosso, Mato Grosso, Brazil \\ ${ }^{4}$ Federal University of Viçosa, Minas Gerais, Brazil \\ Correspondence: Reginaldo A. Medeiros, Federal Insitute of Mato Grosso, Campus Cáceres-Prof. Olegario \\ Baldo, Mato Grosso, Brazil. Tel: 55-065-99689-0756. E-mail: reginaldo.medeiros@cas.ifmt.edu.br
}

$\begin{array}{lc}\text { Received: March 1, } 2019 & \text { Accepted: April 3,2019 Online Published: June 15, } 2019 \\ \text { doi:10.5539/jas.v11n8p138 } & \text { URL: https://doi.org/10.5539/jas.v11n8p138 }\end{array}$

The research is financed by the Foundation for the Support of Research in the state of Mato Grosso, Brazil-FAPEMAT.

\begin{abstract}
The objective of the research was to assess the growth and structural changes of clonal and seed-origin teak trees in monoculture and agroforestry systems. The experiment was established in a randomized complete block design with six replicates. Eight treatments were etablished consisting of combinations of two propagation types (clonal and seed-origin), two types of cultivation systems until the age of 24 months (monoculture and taungya system with maize) and two types of cultivation system after 24 months of age (monoculture and silvopastoral systems).

The data were analyzed by modeling the growth and yield, diameter distribution and diameter class ingrowth. The technical age of thinning was then determined by the percent entries method. Independent of the cultivation system, clonal trees presented greater tree height and diameter than seed-origin trees. Regarding the cultivation systems, systems ending in a monoculture phase presented greater tree height and diameter than systems ending in a silvopastoral phase. In terms of structure, represented by the evolution of diameter distribution, seed-origin trees and systems ending in a silvopastural phase resulted in flatter and broader distributions than clonal trees and final monoculture phase. Overall, the technical age of the first thinning varied from 6 to 9 years, being earlier for clonal trees in monoculture and later for seed-origin trees in systems ending in a silvopastoral phase. The slower growth and greater variability in silvopastoral systems with seed-origin teak tree can be attributed to the genetic variability of the trees associated competition with the brachiaria grass, which also made the plants more susceptible to the attack of pests.
\end{abstract}

Keywords: diameter distribution, teak, agroforestry, monoculture

\section{Introduction}

Teak (Tectona grandis L., Lamiaceae) is one of the main tropical forest species cultivated worldwide, with a planted area of approximately nine million hectares, out of which $88 \%$ located in Asia, $8 \%$ in Africa and $4 \%$ in Latin America (Midgley et al., 2015). In Latin America, Brazil has the largest planted area, comprising 87,502 ha (IBÁ (Brazilian Tree Industry), 2017). The midwest region of Brazil is where most of the teak plantations are concentrated with an area of approximately 90,000 hectares in 2016 (IMEA (Matogrossense Institute of Agropecuária), 2016).

In recent years, efforts have been taken to increase the productivity of teak plantations by choosing sites suitable to the growth of this species, by selecting more productive and adapted genotypes and by drawing site-genotype specific silvicultural prescriptions. Poor decisions upon these silvicultural components have been pointed as 
responsible for unexpected low productivity examples in several countries (Pérez \& Kanninen, 2005; Tonini, Costa, \& Scwengber, 2009).

Teak is considered a plastic species, with good adaptability to ecological conditions different from those of natural occurrence, a fact that led to its cultivation in several regions of the world (Camino \& Aymerich, 2013; Camino \& Morales, 2013). However, achieving high productivity requires more than relying on the species adaptability. In addition, a group of silvicultural and management decisions must be thoroughly planned in order to meet growing conditions as optimal as possible, including understanding and matching edapho-climatic conditions (Fernández-Moya et al., 2015; Golfari, Caser, \& Moura, 1978; Kaosa-ard, 1995; Medeiros, 2016; Pandey \& Brown, 2000; Pelissari, Caldeira, V. S. Santos, \& J. O. P. Santos, 2012; Ugulino, Latorraca, \& Tomazello Filho, 2014), plant breeding, genotype prescription (Costa et al., 2015; Costa, Resende, \& Silva, 2007; FAO (Food and Agriculture Organization of the United Nations), 2015; Schuhli \& Paludzyszyn Filho, 2010) and other silvicultural prescriptions such as soil preparation and fertilization, planting spacing, thinning and pruning (FAO, 2009; Kaosa-ard, 1995; Pelissari, Caldeira, \& Drescher, 2013).

Besides pure plantations, teak has been pointed as an excellent option for agrosilvicultural systems either with agricultural crops (Medeiros et al., 2015; Moretti et al., 2014) or with forages and animal production (Cañadas-L. et al., 2018; Domingos Júnior \& Coelho, 2018). These systems are essentially characterized by being more sustainable when compared to monoculture (Nair, 1985), since it seeks to optimize land use for agriculture, animal production and timber or non-timber tree products, providing periodic production of one or more of these components (Alao \& Shuaibu, 2013). In addition, agroforestry systems are especially important in tropical and subtropical regions where they can be used as a sensible alternative to recuperate degraded areas (Sun et al., 2017).

The taungya and the silvopastoral system are two of the various types of agroforestry systems. The taungya system is characterized by the cultivation of tree species as the main component of the system in a consortium with agricultural crops in the first years (Nair, 1985). The objective is to reduce the plantation and maintenance costs of the forest stand in the initial phase with incomes generated by the agricultural crop (Medeiros et al., 2015; Schlönvoigt \& Beer, 2001). The silvopastoral system consists of animal production on pasture under widely-spaced trees or between tree strips (Nair, 1985). This system has attracted the attention of many producers and breeders, since the consumer market of animal products has given increasingly greater importance to the sustainability of the production and animal welfare (Zanin, Bichel, \& Mangilli, 2016).

Efforts have been made to understand and predict teak growth under different cultivation systems and silvicultural prescriptions in Brazil, such as investigations involving genotypes performance (Costa et al., 2007; Schuhli \& Paludzyszyn Filho, 2010), agroforestry systems (Medeiros et al., 2015; Moretti et al., 2014) and thinning (Helio Garcia Leite, Nogueira, Campos, Takizawa, \& Rodrigues, 2006; Nogueira, Leite, Campos, Souza, \& Couto, 2001; Nogueira, Leite, Campos, Takizawa, \& Couto, 2006). However, studies still lack considering the wide range of silvicultural options in which teak has the potential to be deployed.

Hence, in order to contribute to the development of silvicultural options for teak, the objective of this study was to assess the growth and structural development of teak trees in different cultivation systems such as seed-origin and clonal teak trees under monoculture, agrosilvopastoral and taungya system.

\section{Method}

\subsection{Experimental Data}

The experiment was installed in January 2010 in the municipality of Figueirópolis D'Oeste, Mato Grosso state, midwest Brazil. The experimental area is located under the geographical coordinates of $15^{\circ} 24^{\prime} 27^{\prime \prime} \mathrm{S}$ and $58^{\circ} 45^{\prime} 56^{\prime \prime} \mathrm{W}$ and altitude of $370 \mathrm{~m}$. The climate of the region is Aw, according to Köppen (Alvares, Stape, Sentelhas, Gonçalves, \& Sparovek, 2013), with an annual temperature ranging from $25^{\circ} \mathrm{C}$ to $38^{\circ} \mathrm{C}$ and rainfall around $1,500 \mathrm{~mm}_{\text {year }}{ }^{-1}$. The soil of the area was classified as cambisols, according to the classification of the Brazilian Soil Classification System (Santos et al., 2013), presenting a sandy-loam texture. The place where the experiment was implanted was occupied with pasture (Urochloa brizantha var. Marandu).

The experiment was installed in a randomized complete block design, with six replicates. Each plot had an area of $364 \mathrm{~m}^{2}$, comprising seven teak planting rows in the east-west direction, with six plants per row. The planting spacing was $4 \mathrm{~m} \times 2 \mathrm{~m}$, which resulted in 42 plants per plot, from which only the central 20 trees were measured. 
Eight treatments were evaluated: two propagation types (clonal and seed-origin), two types of teak cultivation systems until the age of 24 months (monoculture and taungya system with maize) and two types of cultivation system after 24 months of age (monoculture and silvopastoral systems), as described below:

CL_MC: clonal plants in monoculture;

CL_TA_MC: clonal plants in taungya system in the early phase, later conducted as monoculture;

CL_MC_SS: clonal plants in monoculture in the early phase, later conducted as silvopastoral system;

CL_TA_SS: clonal plants in taungya system in the early phase, later conducted as silvopastoral system;

SE_MC: seed-origin plants in monoculture;

SE_TA_MC: seed-origin plants in taungya system in the early phase, later conducted as monoculture;

SE_MC_SS: seed-origin plants in monoculture in the early phase, later conducted as silvopastoral system;

SE_TA_SS: seed-origin plants in taungya system in the early phase, later conducted as silvopastoral system.

In the plots where the maize was planted, the soil preparation consisted of two passages of a $15-\mathrm{cm}$ plow followed by one passage of the leveling harrow. After 30 days of teak planting, which was performed in February 2010, the cultivation of the maize cultivar AG 8088 YG was carried out. In February 2011, the maize cultivar BM3061 was planted. Three rows of maize, spaced $0.8 \mathrm{~m}$ and $1.2 \mathrm{~m}$ apart from the teak planting line were planted resuting in 52.500 maize plants per hectare. Fertilization was performed with the application of 120 $\mathrm{kg} \mathrm{ha}^{-1}$ of ammonium between the lines of the agricultural crop. Weed control was performed manually and mechanized in all plots. In the monoculture plots, chemical control was used to eliminate the brachiaria grass at 24 months of age.

\subsection{Data Collection}

The trees in the experimental plots were measured at the ages of $27,36,48,60,72,84$ and 96 months after planting. Tree circumference was measure at $1.30 \mathrm{~m}$ from soil surface, later converted to diameter (dbh). Up to the age of 48 months the total height of all individuals was measured and, from this age onwards, only the height of the $9^{\text {th }}, 10^{\text {th }}, 11^{\text {th }}$ and $12^{\text {th }}$ tree, according to the measuring order of the first inventory, were measured using a 14-m ruler pole. For taller trees, tree height was visually estimated in comparison to the ruler pole. The height of the non-measured trees was estimated using Gompertz equation fit by treatment (Table 1). At the age of 48 months, teak plants were attacked by Maconellicoccus hirsutus (Green) (Silva et al., 2014).

Table 1. Parameters of the Gompertz model relating tree total height $(\mathrm{Ht})$ to diameter at $1.30 \mathrm{~m}(\mathrm{dbh})$ and respective goodness-of-fit statistics residual standard error (Syx) and Pearson correlation coefficient between the estimated and observed tree heights (Ryy) for an experiment of cultivation systems of Tectona grandis in the state of Mato Grosso, midwest Brazil

\begin{tabular}{|c|c|c|c|}
\hline Treatment $^{1}$ & Equation $^{2}$ & Syx & Ryŷy \\
\hline $\mathrm{CL} \_\mathrm{MC}$ & $\mathrm{Ht}=18.593766 \exp [-\exp (0.871734-0.130132 \mathrm{dbh})]$ & 0.70 & 96.84 \\
\hline CL_TA_MC & $\mathrm{Ht}=19.658192 \exp [-\exp (0.906132-0.124859 \mathrm{dbh})]$ & 0.71 & 96.91 \\
\hline CL_MC_SS & $\mathrm{Ht}=19.302478 \exp [-\exp (1.043292-0.156955 \mathrm{dbh})]$ & 0.85 & 95.18 \\
\hline CL_TA_SS & $\mathrm{Ht}=15.482321 \exp [-\exp (1.178656-0.205769 \mathrm{dbh})]$ & 0.63 & 93.00 \\
\hline SE_MC & $\mathrm{Ht}=12.829978 \exp [-\exp (1.090819-0.242080 \mathrm{dbh})]$ & 0.68 & 95.12 \\
\hline SE_TA_MC & $\mathrm{Ht}=13.066952 \exp [-\exp (1.105060-0.237560 \mathrm{dbh})]$ & 0.75 & 92.92 \\
\hline SE_MC_SS & $\mathrm{Ht}=12.474106 \exp [-\exp (1.233085-0.273728 \mathrm{dbh})]$ & 0.71 & 93.54 \\
\hline SE_TA_SS & $\mathrm{Ht}=12.175862 \exp [-\exp (1.262837-0.289972 \mathrm{dbh})]$ & 0.81 & 89.90 \\
\hline
\end{tabular}

Note. ${ }^{1}=$ Codes stands for treatment composition such as: $\mathrm{CL}=$ clone; $\mathrm{SE}=$ Seed-origin; $\mathrm{MC}=$ Monoculture system; TA = Taungya system in the initial phase and $\mathrm{SS}=$ silvopastoral system. ${ }^{2}=$ all coefficients were significant in the $t$ test at $5 \%$ significance level.

\subsection{Data Analysis}

To check whether there was a difference in the trend across time for total tree height, dbh and basal area (G), Gompertz model was used to model these variables as a function of age for every treatment:

$$
\mathrm{y}=\beta_{0} \mathrm{e}^{-\mathrm{e}^{\left(\beta_{1}-\beta_{2} A\right)}}+\varepsilon
$$


where, $\mathrm{y}$ is the variable of interest $(\mathrm{Ht}, \mathrm{dbh}$ or $\mathrm{G}), \beta$ 's are the parameters to be estimated via Gauss-Newton method, $A$ is the age and $\varepsilon$ is the random error. Differences in the trend across time was assessed by checking for pair-wise model equivalence using a model identity test (Regazzi \& Silva, 2010):

$$
\begin{gathered}
\mathrm{F}=\left(\mathrm{n}-\mathrm{p}_{\mathrm{c}}\right)\left[\Sigma_{\mathrm{i}}\left(\mathrm{Y}_{\mathrm{i}}-\widehat{\mathrm{Y}}_{\mathrm{i} . \mathrm{r}}\right)^{2}-\Sigma_{\mathrm{i}}\left(\mathrm{Y}_{\mathrm{i}}-\widehat{\mathrm{Y}}_{\mathrm{i}, \mathrm{c}}\right)^{2}\right] /\left(\mathrm{p}_{\mathrm{c}}-\mathrm{p}_{\mathrm{r}}\right) \Sigma_{\mathrm{i}}\left(\mathrm{Y}_{\mathrm{i}}-\widehat{\mathrm{Y}}_{\mathrm{i}, \mathrm{c}}\right)^{2} \\
\sim \mathrm{F}\left(\alpha ;\left(\mathrm{p}_{\mathrm{c}}-\mathrm{p}_{\mathrm{r}}\right) \text { and }\left(\mathrm{n}-\mathrm{p}_{1}\right) \text { degrees of freedom }\right)
\end{gathered}
$$

where, $\widehat{Y}_{\mathrm{i}, \mathrm{r}}$ is the ith estimate of the reduced model (single equation for the pair of treatments under analysis); $\widehat{Y}_{i, c}$ is the ith estimate of the complete model (grouping of treatment-specific equations) $\mathrm{Y}_{\mathrm{i}}$ is the observed value of the interest variable; $p_{c}$ is the number of coefficients in the complete model and $p_{r}$ is the number of coefficients in the reduced model. Because pairwise comparisons were made, $p_{c}=6$ and $p_{r}=3$. Equations goodness-of-fit was assessed with the Pearson correlation coefficient $\left(\mathrm{R}_{\mathrm{y} \hat{y}}, 3\right)$, residual standard error $\left(\mathrm{S}_{\mathrm{yx}}, 4\right)$ and graphic analysis of the percent residuals $(\mathrm{PR}, 5)$ :

$$
\begin{gathered}
\mathrm{R}_{\mathrm{y} \hat{\mathrm{y}}}=\mathrm{n}^{-1}\left[\sum_{\mathrm{i}=1}^{\mathrm{n}}\left(\hat{\mathrm{y}}_{\mathrm{i}}-\hat{\mathrm{y}}_{\mathrm{m}}\right)\left(\mathrm{y}_{\mathrm{i}}-\overline{\mathrm{y}}\right)\right] / \sqrt{\left[\mathrm{n}^{-1} \sum_{\mathrm{i}=1}^{\mathrm{n}}\left(\hat{\mathrm{y}}_{\mathrm{i}}-\hat{\mathrm{y}}_{\mathrm{m}}\right)^{2}\right]\left[\mathrm{n}^{-1} \sum_{\mathrm{i}=1}^{\mathrm{n}}\left(\mathrm{y}_{\mathrm{i}}-\overline{\mathrm{y}}\right)^{2}\right]} ; \hat{\mathrm{y}}_{\mathrm{m}}=\mathrm{n}^{-1} \sum_{\mathrm{i}=1}^{\mathrm{n}} \hat{\mathrm{y}}_{\mathrm{i}} \\
\mathrm{S}_{\mathrm{yx}}=\sqrt{\frac{\left(\sum \mathrm{n}_{\mathrm{i}=1}\left(\mathrm{Y}_{\mathrm{i}}-\hat{\mathrm{Y}}_{\mathrm{i}}\right)^{2}\right.}{\mathrm{n}-\mathrm{p}}} \\
\mathrm{PR}=100 \times \frac{\hat{\mathrm{y}}_{\mathrm{i}}-\mathrm{y}_{1}}{\mathrm{y}_{\mathrm{i}}}
\end{gathered}
$$

where, $\mathrm{y}_{\mathrm{I}}$ and $\hat{\mathrm{y}}_{\mathrm{I}}$ are the ith observed and estimated values for the interest variable $(\mathrm{y}) ; \overline{\mathrm{y}}$ is the mean value for $\mathrm{y} ; \hat{\mathrm{y}}_{\mathrm{m}}$ is the mean of the estimated values; $\mathrm{n}$ is the number of observations and $\mathrm{p}$ is the number of coefficients in the models.

Besides different trends in mean values of total height, dbh and basal area, propagation and cultivation system might result in substantial structural changes across stand development, which is a sensible information for silviculturists. Therefore, the 2-parameter Weibull (6) probability density function was used to describe diameter distribution throughout stand development. The diameter class amplitude was established as $1 \mathrm{~cm}$ and a plot-wise fitting was performed with the software FitFD (Neuroforest, 2012).

$$
f(x)=\left(\frac{\gamma}{\beta}\right)\left(\frac{x}{\beta}\right)^{(\gamma-1)} e^{-\left(\frac{x}{\beta}\right)^{\gamma}}
$$

where, $f(x)$ is the probability density function, $x$ is the diameter class center $(x \geq 0), \beta$ is the scale parameter $(\beta>$ $0)$ and $\gamma$ the form parameter $(\gamma>0)$.

To build a diameter distribution projection model, the equations 7, 8, 9, and 10 were fit to project the parameters of Weibull model throughout time. The Quasi-Newton algorithm was used for model fitting with the software Statistica (StatSoft, 2014).

$$
\begin{gathered}
\gamma_{2}=\gamma_{1}\left(\frac{\mathrm{A}_{1}}{\mathrm{~A}_{2}}\right)+\propto_{1}\left[1-\left(\frac{\mathrm{A}_{1}}{\mathrm{~A}_{2}}\right)\right]+\varepsilon \\
\beta_{2}=\beta_{1}\left(\frac{\mathrm{A}_{1}}{\mathrm{~A}_{2}}\right)+\propto_{2}\left[1-\left(\frac{\mathrm{A}_{1}}{\mathrm{~A}_{2}}\right)\right] \operatorname{Dmax}_{2}+\varepsilon \\
\operatorname{Dmax}_{2}=\operatorname{Dmax}_{1}\left(\frac{\mathrm{A}_{1}}{\mathrm{~A}_{2}}\right)+\propto_{3}\left[1-\left(\frac{\mathrm{A}_{1}}{\mathrm{~A}_{2}}\right)\right]+\varepsilon \\
q_{2}=\propto_{4}+\propto_{5} q_{1}+\varepsilon
\end{gathered}
$$

where, $\beta$ and $\gamma$ are parameters of the Weibull function in the current $\left(\beta_{1}\right.$ and $\left.\gamma_{1}\right)$ and future $\left(\beta_{2}\right.$ and $\left.\gamma_{2}\right)$ ages, $q$ is the quadratic mean diameter in the current $\left(q_{1}\right)$ and future $\left(q_{2}\right)$ ages, Dmax is the maximum diameter in the current $\left(\operatorname{Dmax}_{1}\right)$ and future $\left(\operatorname{Dmax}_{2}\right)$ ages and $A$ is the current $\left(\mathrm{A}_{1}\right)$ and future $\left(\mathrm{A}_{2}\right)$ ages, $x$ is the diameter class center, $\alpha, \beta$ and $\gamma$ are parameters to the estimated and $\varepsilon$ is the random error term.

For each treatment, the current number of trees was the actual observed value (Nobs) for each age. Because it was not possible to fit the equation for estimating the number of trees in the future ages of 108 and 120 months, we used the same number of trees as at 96 months.

To recover the number of trees per diameter class the Equation 11 was used, which is a transformation of the Weibull function:

$$
\operatorname{Nrec}_{x}=\left[\mathrm{e}^{-\left(\frac{\mathrm{x}_{\mathrm{i}}}{\beta}\right)^{\gamma}}-\mathrm{e}^{-\left(\frac{\mathrm{x}_{\mathrm{s}}}{\beta}\right)^{\gamma}}\right] \operatorname{Nobs}_{j}
$$


where, $N r e c_{x}$ is the number of trees recovered per diamater class at a given age; $x_{i}$ e $x_{s}$ are the upper and lower limit of the diameter class and Nobs is the observed number of trees at a given age $\mathrm{j}$.

The validation of this diameter distribution projection model was made by comparing the observed and estimated distribution at the age of 96 months, using the L\&O procedure (Leite \& Oliveira, 2002).

The ingrowth in new diameter classes was calculated as in Garcia (1999), Medeiros et al. (2017) and Nogueira et al. (2001) based on the differentiating diameter (DD), which is the point at which the difference between two density probability functions, in distinct occasions, intersect. That is, the ingrowth in successive diameter classes become non-significant.

This point can be estimated by the parameter $\theta_{3}$ in the expo-linear model (12). Therefore, to identify the technical age of thinning (TAT), given by the DD, the expolinear model was fit using the simplex algorithm in the software Statistica (StatSoft, 2014).

$$
\text { MPI }=\left(\frac{\theta_{1}}{\theta_{2}}\right) \operatorname{Ln}\left[1+\exp ^{\left(\theta_{2}\left(I-\theta_{3}\right)\right.}\right]+\varepsilon, \varepsilon \sim \mathrm{NID}\left(0, \sigma^{2}\right)
$$

where, MPI is the mean monthly percent tree ingrowth, $A$ is the stand age in months, $\theta_{1}$ is the parameter that indicates the maximum absolute growth of the tree ingrowth in the linear phase of the curve, $\theta_{2}$ is the parameter that indicates the maximum relative growth of the percent tree ingrowth in the exponential phase of the curve, $\theta_{3}$ is the parameter that corresponds to the technical age of thinning and $\varepsilon$ is the random error.

\section{Results}

\subsection{Growth and Yield}

There was a distinctly higher precision (Syx) and accuracy (Ryŷ) of the Gompertz yield equations for clonal than for seed-origin trees. The systems which had a silvopastoral phase had the lowest values for these goodness-of-fit statistics, which is a result of the higher variability of the analyzed variables in these systems. 
Table 2. Parameters of the Gompertz model relating tree total height $(\mathrm{Ht})$, diameter at $1.30 \mathrm{~m}(\mathrm{dbh})$, and basal area $(G)$ to stand age and respective goodness-of-fit statistics residual standard error (Syx) and Pearson correlation coefficient between the estimated and observed tree heights (Ryŷ) for an experiment of cultivation system of Tectona grandis in the state of Mato Grosso, midwest Brazil

\begin{tabular}{|c|c|c|c|c|}
\hline Cultivation system $^{1}$ & Equation $^{2}$ & $\mathbf{F}^{3}$ & Syx & Ryŷy \\
\hline CL_MC & $\mathrm{Ht}=16.120264 \exp [-\exp (1.004400-0.038609 \mathrm{I})]$ & $\mathrm{b}$ & 0.73 & 97.29 \\
\hline CL_TA_MC & $\mathrm{Ht}=16.275785 \exp [-\exp (1.074729-0.040720 \mathrm{I})]$ & $\mathrm{a}$ & 0.71 & 97.59 \\
\hline CL_MC_SS & $\mathrm{Ht}=17.637485 \exp [-\exp (0.700592-0.026105 \mathrm{I})]$ & $\mathrm{c}$ & 1.06 & 93.91 \\
\hline CL_TA_SS & $\mathrm{Ht}=15.086301 \exp [-\exp (0.943612-0.036711 \mathrm{I})]$ & $\mathrm{d}$ & 0.90 & 95.30 \\
\hline SE_MC & $\mathrm{Ht}=11.752373 \exp [-\exp (0.965770-0.042412 \mathrm{I})]$ & $\mathrm{f}$ & 1.14 & 88.35 \\
\hline SE_TA_MC & $\mathrm{Ht}=12.045091 \exp [-\exp (0.830852-0.039841 \mathrm{I})]$ & $\mathrm{e}$ & 0.94 & 90.96 \\
\hline SE_MC_SS & $\mathrm{Ht}=11.330674 \exp [-\exp (0.462431-0.026189 \mathrm{I})]$ & $\mathrm{g}$ & 1.38 & 76.66 \\
\hline SE_TA_SS & $\mathrm{Ht}=11.245013 \exp [-\exp (0.545429-0.029094 \mathrm{I})]$ & $\mathrm{g}$ & 1.10 & 84.41 \\
\hline CL_MC & $\mathrm{dbh}=21.623532 \exp [-\exp (1.092703-0.031004 \mathrm{I})]$ & $\mathrm{a}$ & 1.23 & 96.26 \\
\hline CL_TA_MC & $\mathrm{dbh}=21.189126 \exp [-\exp (1.076470-0.031941 \mathrm{I})]$ & $\mathrm{a}$ & 1.18 & 96.37 \\
\hline CL_MC_SS & $\mathrm{dbh}=23.718204 \exp [-\exp (0.858343-0.020045 \mathrm{I})]$ & $\mathrm{b}$ & 1.59 & 91.89 \\
\hline CL_TA_SS & $\mathrm{dbh}=26.532956 \exp [-\exp (0.846705-0.016718 \mathrm{I})]$ & $\mathrm{c}$ & 1.29 & 94.21 \\
\hline SE_MC & $\mathrm{dbh}=22.510258 \exp [-\exp (0.820983-0.016164 \mathrm{I})]$ & $\mathrm{d}$ & 1.76 & 86.15 \\
\hline SE_TA_MC & $\mathrm{dbh}=23.169856 \exp [-\exp (0.779001-0.015283 \mathrm{I})]$ & $\mathrm{d}$ & 1.56 & 88.14 \\
\hline SE_MC_SS & $\mathrm{dbh}=564.340845 \exp [-\exp (1.612153-0.002482 \mathrm{I})]$ & e & 1.65 & 75.69 \\
\hline SE_TA_SS & $\mathrm{dbh}=1304.815397 \exp [-\exp (1.765497-0.002102 \mathrm{I})]$ & e & 1.47 & 79.58 \\
\hline CL_MC & $\mathrm{G}=46.518019 \exp [-\exp (1.770676-0.030643 \mathrm{I})]$ & a & 3.47 & 95.14 \\
\hline CL_TA_MC & $G=46.383075 \exp [-\exp (1.711431-0.029984 \mathrm{I})]$ & a & 3.51 & 94.86 \\
\hline CL_MC_SS & $\mathrm{G}=64.045899 \exp [-\exp (1.520134-0.017952 \mathrm{I})]$ & $\mathrm{b}$ & 4.25 & 89.33 \\
\hline CL_TA_SS & $\mathrm{G}=81.020260 \exp [-\exp (1.531387-0.015139 \mathrm{I})]$ & $\mathrm{c}$ & 3.11 & 93.45 \\
\hline SE_MC & $\mathrm{G}=80.345768 \exp [-\exp (1.543254-0.012626 \mathrm{I})]$ & $\mathrm{d}$ & 3.96 & 82.72 \\
\hline SE_TA_MC & $\mathrm{G}=79.060419 \exp [-\exp (1.503875-0.012374 \mathrm{I})]$ & $\mathrm{d}$ & 3.55 & 85.15 \\
\hline SE_MC_SS & $G=17657.992075 \exp [\exp (2.250640-0.002771 \mathrm{I})]$ & $\mathrm{e}$ & 2.90 & 73.99 \\
\hline SE_TA_SS & $\mathrm{G}=43479.721296 \exp [-\exp (2.350018-0.002637 \mathrm{I})]$ & $\mathrm{e}$ & 2.74 & 77.32 \\
\hline
\end{tabular}

Note. ${ }^{1}$ Codes stands for treatment composition such as: $\mathrm{CL}=$ clone; $\mathrm{SE}=$ Seed-origin; $\mathrm{MC}=\mathrm{Monoculture}$ system; $\mathrm{TA}=$ Taungya system in the initial phase and $\mathrm{SS}=$ silvopastoral system. ${ }^{2}$ All coefficients were significant in the $t$ test at $5 \%$ significance level. ${ }^{3}$ Same letters indicate model equivalence in the model identity at $5 \%$ significance level.

The fact the predicted tree height for the age of 108 months (Figure 1) approached the Gompertz equations's asymptotes $\left(\beta_{0}\right)$ indicates that the teak trees are have approached a stagnation phase in this variable. However, in terms of dbh and basal area, this trend was only observed for clonal plants with a final monoculture phase.

For clonal trees in systems with a silvopastoral (CL_MC_SS and CL_TA_SS) and monoculture (SE_MC and SE_TA_MC) phase, the results suggest that growth stagnation has not yet occurred or that growth is slower, since the growth rate is lower. The estimated equations for diameter and basal area of seed-origin trees in silvipastoral systems (SE_TA_SS and SE_MC_SS) did not present biologically reliable asymptotes $\left(\beta_{0}\right)$, whereas the growth rate (parameter $\beta_{1}$ ) was superior to the others, which suggests the growth recovery after a certain age due to a lesser competition with brachiaria grass. Table 3 shows the reduced model for the non-signicant pair-wise model identity tests. Grouped treatments can be interpreted as presenting the same growth trend. 
Table 3. Parameters of the Gompertz model fitted for pair of treatments in of an experiment of cultivation systems of Tectona grandis in the state of Mato Grosso, midwest Brazil

\begin{tabular}{llcc}
\hline Treatment grouping & Equation $^{2}$ & $\mathbf{S y x}^{\mathbf{3}}$ & $\mathbf{R y}^{\mathbf{4}}$ \\
\hline SE_MC_SS/SE_TA_SS & $\mathrm{Ht}=11.275543 \exp [-\exp (0.502549-0.027648 \mathrm{~A})]$ & 1.26 & 80.28 \\
\hdashline CL_MC/CL_TA_MC & $\mathrm{dbh}=21.405187 \exp [-\exp (1.083901-0.031452 \mathrm{~A})]$ & 1.21 & 96.30 \\
SE_MC/SE_TA_MC & $\mathrm{dbh}=22.957609 \exp [-\exp (0.800341-0.015633 \mathrm{~A})]$ & 1.66 & 87.11 \\
SE_MC_SS/SE_TA_SS & $\mathrm{dbh}=979.386738 \exp [-\exp (1.715515-0.002212 \mathrm{~A})]$ & 1.57 & 77.53 \\
\hdashline CL_MC/CL_TA_MC & $\mathrm{G}=46.474374 \exp [-\exp (1.739789-0.030284 \mathrm{~A})]$ & 3.50 & 95.00 \\
SE_MC/SE_TA_MC & $\mathrm{G}=79.737377 \exp [-\exp (1.522964-0.012491 \mathrm{~A})]$ & 3.76 & 83.92 \\
SE_MC_SS/SE_TA_SS & $\mathrm{G}=28919.543154 \exp [-\exp (2.305493-0.002683 \mathrm{~A})]$ & 2.83 & 75.59 \\
\hline
\end{tabular}

Note. ${ }^{1}$ Codes stands for treatment composition such as: $\mathrm{CL}=$ clone; $\mathrm{SE}=$ Seed-origin; $\mathrm{MC}=$ Monoculture system; $\mathrm{TA}=$ Taungya system in the initial phase and $\mathrm{SS}=$ silvopastoral system. ${ }^{2}$ All coefficients were significant in the $\mathrm{t}$ test $\mathrm{t} 5 \%$ significance level. ${ }^{3}$ residual standard error. ${ }^{4}$ Pearson correlation coefficient between the estimated and observed tree values.
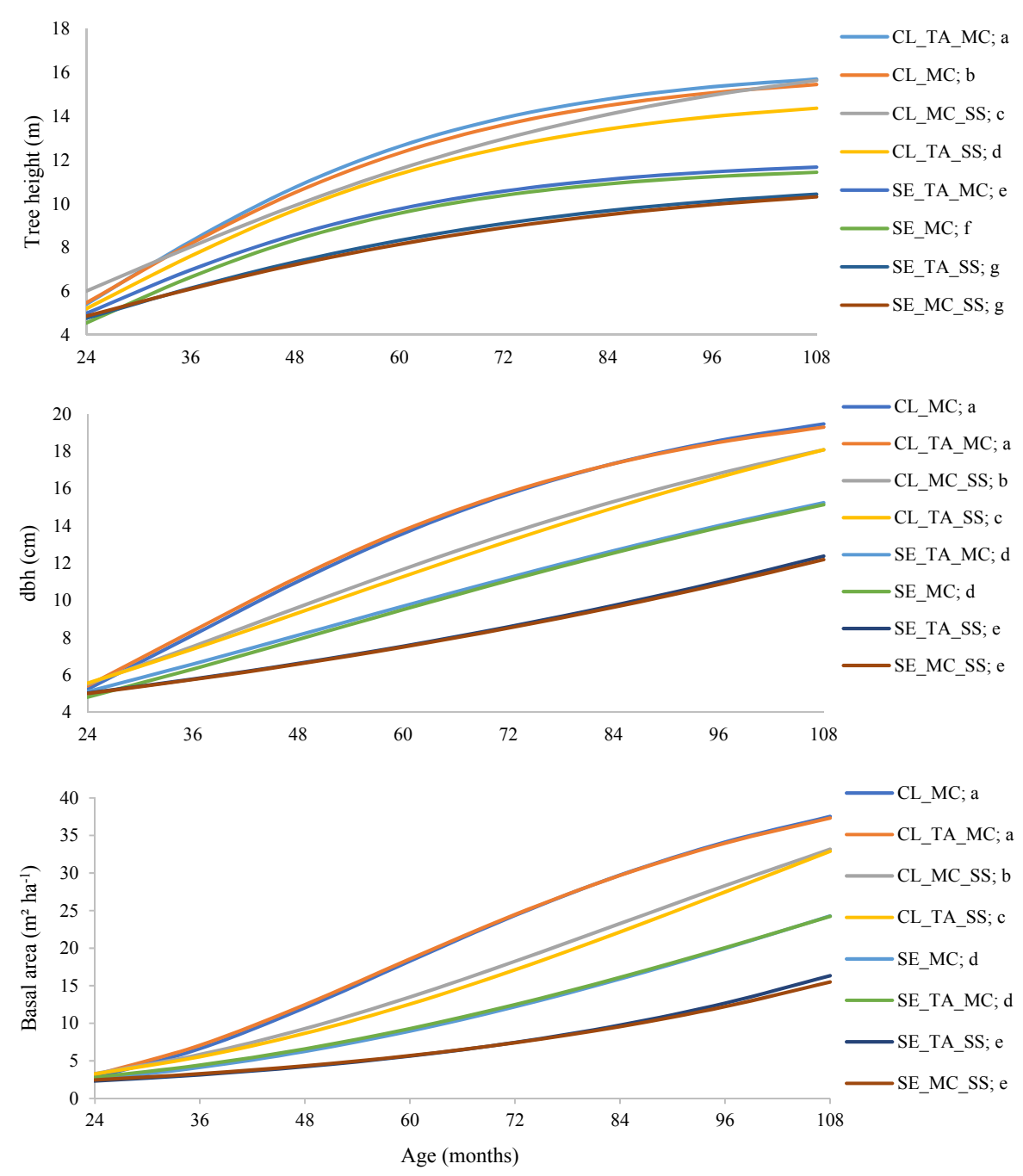

Figure 1. Growth curves of total tree height, diameter at 1.30 above soil surface (dbh) and basal area for an experiment of cultivation systems for Tectona grandis in the estate of Mato Grosso, midwest Brazil

Note. Codes stands for treatment composition such as: $\mathrm{CL}=$ clone; $\mathrm{SE}=$ Seed-origin; $\mathrm{MC}=$ Monoculture system; $\mathrm{TA}=$ Taungya system in the initial phase and SS = silvopastoral system. In the legend, treatments followed by same lowercase letters present no significant growth trend ( $p>0.05$ in F test of the model identity test). 


\subsection{Structural Development}

The system of equations that makes up the diameters distribution model (MDD) used in this study presented biological consistency when describing the behavior of diameter distribution throughout age (Table 4). It was observed that the gamma parameter $(\gamma)$ presented the worst fit for most treatments. Nevertheless, a correlation between the variables at current and future ages can be considered satisfactory for the data of all treatments (Figure 2).

Table 4. Equation of the diameter distribution projection model for different cultivation systems in the state of Mato Grosso, Midwest Brazil

\begin{tabular}{|c|c|c|}
\hline Cultivation system $^{1}$ & Equation $^{2}$ & $\mathbf{R y} \hat{\mathbf{y}}^{3}$ \\
\hline \multirow{4}{*}{ CL_MC } & $\gamma 2=\gamma 1(\mathrm{~A} 1 / \mathrm{A} 2)+26.547568[1-(\mathrm{A} 1 / \mathrm{A} 2)]$ & 80.84 \\
\hline & $\beta 2=\beta 1(\mathrm{~A} 1 / \mathrm{A} 2)+\{1.569447[1-(\mathrm{A} 1 / \mathrm{A} 2)] \mathrm{Dmax} 2\}$ & 98.99 \\
\hline & $\operatorname{Dmax} 2=\operatorname{Dmax} 1(\mathrm{I} 1 / \mathrm{I} 2)+23.098079[1-(\mathrm{I} 1 / \mathrm{I} 2)]$ & 95.26 \\
\hline & $\mathrm{q} 2=3.48094+0.882942 \mathrm{q} 1$ & 98.25 \\
\hline \multirow{4}{*}{ CL_TA_MC } & $\gamma 2=\gamma 1(\mathrm{~A} 1 / \mathrm{A} 2)+24.820885[1-(\mathrm{A} 1 / \mathrm{A} 2)]$ & 0.00 \\
\hline & $\beta 2=\beta 1(\mathrm{~A} 1 / \mathrm{A} 2)+\{1.530568[1-(\mathrm{A} 1 / \mathrm{A} 2)] \mathrm{Dmax} 2\}$ & 98.27 \\
\hline & $\operatorname{Dmax} 2=\operatorname{Dmax} 1(\mathrm{~A} 1 / \mathrm{A} 2)+23.453643[1-(\mathrm{A} 1 / \mathrm{A} 2)]$ & 93.71 \\
\hline & $\mathrm{q} 2=3.542951+0.877394 \mathrm{q} 1$ & 97.86 \\
\hline \multirow{4}{*}{ CL_MC_SS } & $\gamma 2=\gamma 1(\mathrm{~A} 1 / \mathrm{A} 2)+23.678059[1-(\mathrm{A} 1 / \mathrm{A} 2)]$ & 0.00 \\
\hline & $\beta 2=\beta 1(\mathrm{~A} 1 / \mathrm{A} 2)+\{1.453442[1-(\mathrm{A} 1 / \mathrm{A} 2)] \operatorname{Dmax} 2\}$ & 98.08 \\
\hline & $\operatorname{Dmax} 2=\operatorname{Dmax} 1(\mathrm{~A} 1 / \mathrm{A} 2)+21.712772[1-(\mathrm{A} 1 / \mathrm{A} 2)]$ & 95.47 \\
\hline & $\mathrm{q} 2=2.311975+0.958449 \mathrm{q} 1$ & 99.47 \\
\hline \multirow{4}{*}{ CL_TA_SS } & $\gamma 2=\gamma 1(\mathrm{~A} 1 / \mathrm{A} 2)+31.889891[1-(\mathrm{A} 1 / \mathrm{A} 2)]$ & 64.11 \\
\hline & $\beta 2=\beta 1(\mathrm{~A} 1 / \mathrm{A} 2)+\{1.561934[1-(\mathrm{A} 1 / \mathrm{A} 2)] \mathrm{Dmax} 2\}$ & 99.29 \\
\hline & $\operatorname{Dmax} 2=\operatorname{Dmax} 1(\mathrm{~A} 1 / \mathrm{A} 2)+19.911468[1-(\mathrm{A} 1 / \mathrm{A} 2)]$ & 93.72 \\
\hline & $\mathrm{q} 2=1.952914+0.985670 \mathrm{q} 1$ & 98.86 \\
\hline \multirow{4}{*}{ SE_MC } & $\gamma 2=10.088633(\mathrm{~A} 1 / \mathrm{A} 2)+\gamma 1[1-(\mathrm{A} 1 / \mathrm{A} 2)]$ & 10.89 \\
\hline & $\beta 2=\beta 1(\mathrm{~A} 1 / \mathrm{A} 2)+\{1.460738[1-(\mathrm{A} 1 / \mathrm{A} 2)] \mathrm{Dmax} 2\}$ & 98.41 \\
\hline & $\operatorname{Dmax} 2=\operatorname{Dmax} 1(\mathrm{~A} 1 / \mathrm{A} 2)+19.102695[1-(\mathrm{A} 1 / \mathrm{A} 2)]$ & 90.71 \\
\hline & $\mathrm{q} 2=1.330183+1.021292 \mathrm{q} 1$ & 98.84 \\
\hline \multirow{4}{*}{ SE_TA_MC } & $\gamma 2=\gamma 1(\mathrm{~A} 1 / \mathrm{A} 2)+9.996672[1-(\mathrm{A} 1 / \mathrm{A} 2)]$ & 0.00 \\
\hline & $\beta 2=\beta 1(\mathrm{~A} 1 / \mathrm{A} 2)+\{1.396344[1-(\mathrm{A} 1 / \mathrm{A} 2)] \mathrm{Dmax} 2\}$ & 98.84 \\
\hline & $\operatorname{Dmax} 2=\operatorname{Dmax} 1(\mathrm{~A} 1 / \mathrm{A} 2)+19.332409[1-(\mathrm{A} 1 / \mathrm{A} 2)]$ & 92.53 \\
\hline & $\mathrm{q} 2=1.378734+1.012796 \mathrm{q} 1$ & 99.36 \\
\hline \multirow{4}{*}{ SE_MC_SS } & $\gamma 2=\gamma 1(\mathrm{~A} 1 / \mathrm{A} 2)+10.111852[1-(\mathrm{A} 1 / \mathrm{A} 2)]$ & 69.71 \\
\hline & $\beta 2=\beta 1(\mathrm{~A} 1 / \mathrm{A} 2)+\{1.304273[1-(\mathrm{A} 1 / \mathrm{A} 2)] \mathrm{Dmax} 2\}$ & 91.94 \\
\hline & $\operatorname{Dmax} 2=\operatorname{Dmax} 1(\mathrm{~A} 1 / \mathrm{A} 2)+15.475476[1-(\mathrm{A} 1 / \mathrm{A} 2)]$ & 82.86 \\
\hline & $\mathrm{q} 2=0.253690^{*}+1.116746 \mathrm{q} 1$ & 92.39 \\
\hline \multirow{4}{*}{ SE_TA_SS } & $\gamma 2=\gamma 1(\mathrm{~A} 1 / \mathrm{A} 2)+11.298025[1-(\mathrm{A} 1 / \mathrm{A} 2)]$ & 0.00 \\
\hline & $\beta 2=\beta 1(\mathrm{~A} 1 / \mathrm{A} 2)+\{1.454461[1-(\mathrm{A} 1 / \mathrm{A} 2)] \mathrm{Dmax} 2\}$ & 88.23 \\
\hline & $\operatorname{Dmax} 2=\operatorname{Dmax} 1(\mathrm{~A} 1 / \mathrm{A} 2)+13.938322[1-(\mathrm{A} 1 / \mathrm{A} 2)]$ & 71.47 \\
\hline & $\mathrm{q} 2=-0.502261^{*}+1.220476 \mathrm{q} 1$ & 86.24 \\
\hline
\end{tabular}

Note. ${ }^{1}$ Codes stands for treatment composition such as: $\mathrm{CL}=$ clone; $\mathrm{SE}=$ Seed-origin; $\mathrm{MC}=$ Monoculture system; TA = Taungya system in the initial phase and $\mathrm{SS}=$ silvopastoral system. ${ }^{2}$ All coefficients were significant in the $\mathrm{t}$ test $\mathrm{t} 5 \%$ significance level, except by those marked with " $" *$. ${ }^{3}$ Pearson correlation coefficient between the estimated and observed values. 

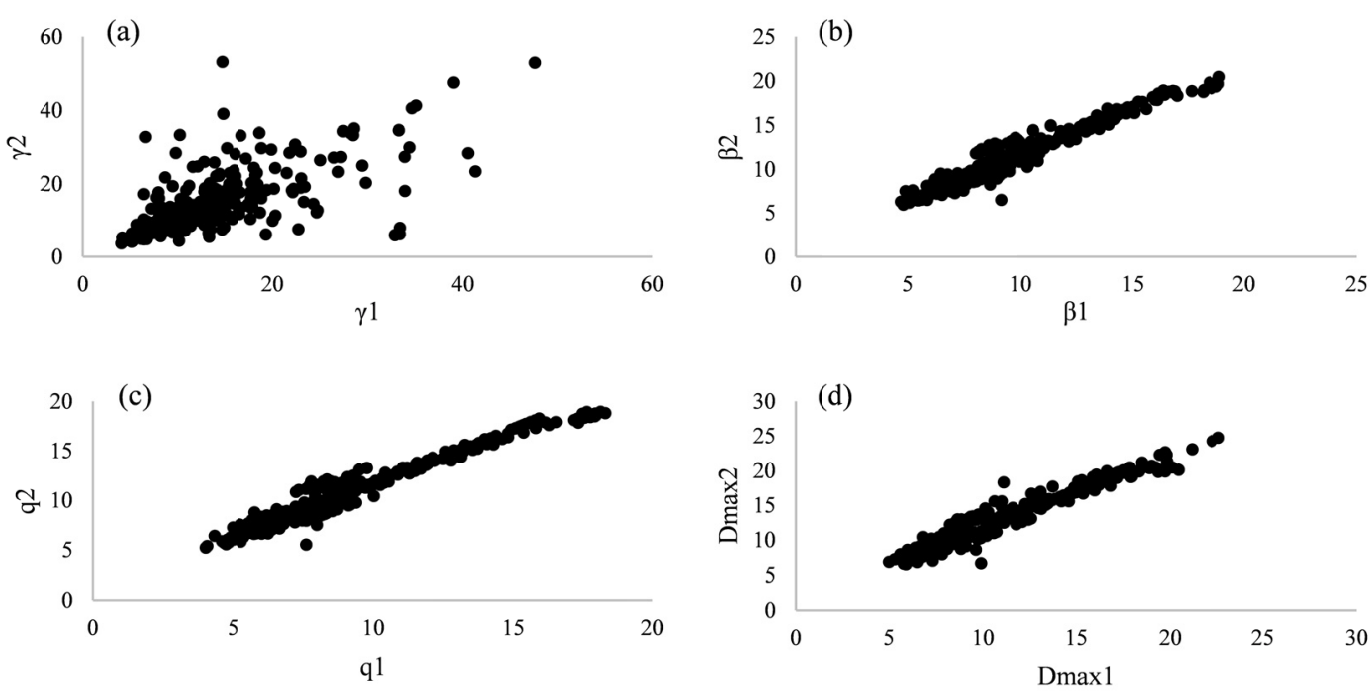

Figure 2. Correlation between the variables that compound the system of equations of the diameter distribution projection model; considering the treatments altogether. $\gamma$ is a shape parameter, $\beta$ is the scale parameter, $q$ is the mean quadratic diameter, and Dmax is the maximum diameter, in current (1) and future (2) ages

At 96 months, which was the last evaluated age, the diamter distribution for all treatments presented a certain level of left-skewness, which is a characteristic of the Weibull distribution when the gamma parameter is greater than 3.6 (Table A1). According to the statistical procedure proposed by (Leite \& Oliveira, 2002), there was no significant difference between the estimated and observed diameter distributions for the systems that ended in with a monoculture phase (Figure 3). The only significant difference between the observed and the estimated diameter distribution in the $\mathrm{L} \& \mathrm{O}$ procedure was found for the treatments which had a silvopastoral phase. This can be attributed to the larger variability in these systems.
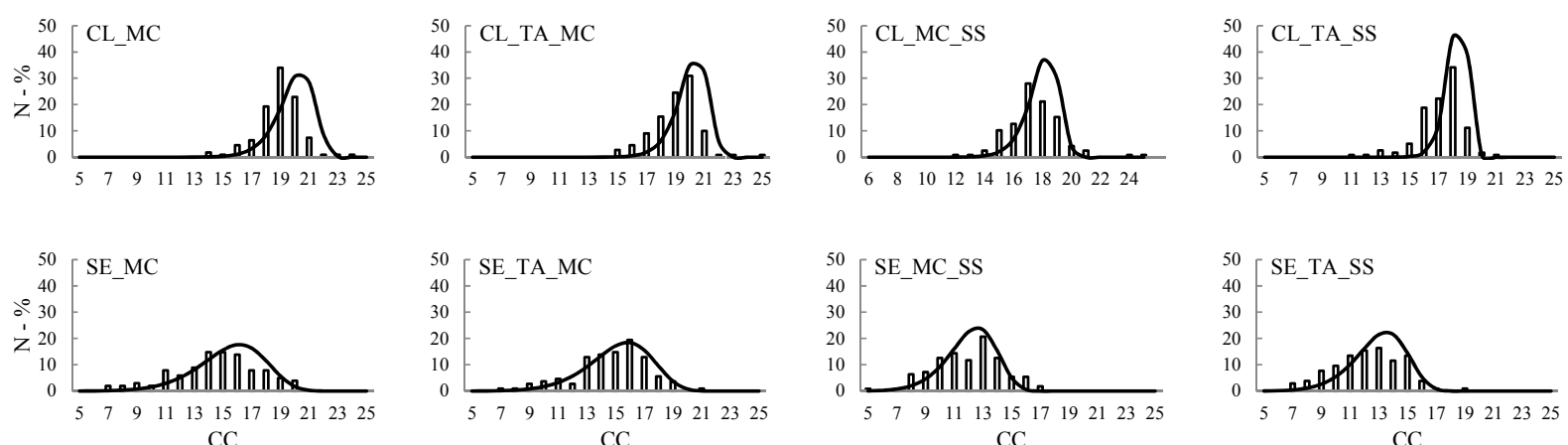

Figure 3. Diameter distribution at 96 for different cultivation systems of Tectona grandis in the state of Mato Grosso, midwest Brazil

Note. $\mathrm{N}$ is the tree relative frequency and $\mathrm{CC}$ is the class center. Plot code codes stands for treatment composition such as: $\mathrm{CL}=$ clone; $\mathrm{SE}=$ Seed-origin; $\mathrm{MC}=$ Monoculture system; $\mathrm{TA}=$ Taungya system in the initial phase and $\mathrm{SS}=$ silvopastoral system.

For all cultivation systems, the diameter distribution reflected the expected pattern for even aged-stands. With age, the curves moved towards right and flattened (Figure 4). This flatter shape is caused by the decrease in the gama $(\gamma)$ parameter of the Weibull function with stand age (Table A1), which was more pronounced for the systems involving seed-origin trees and clonal trees ending with a monoculture phase. 

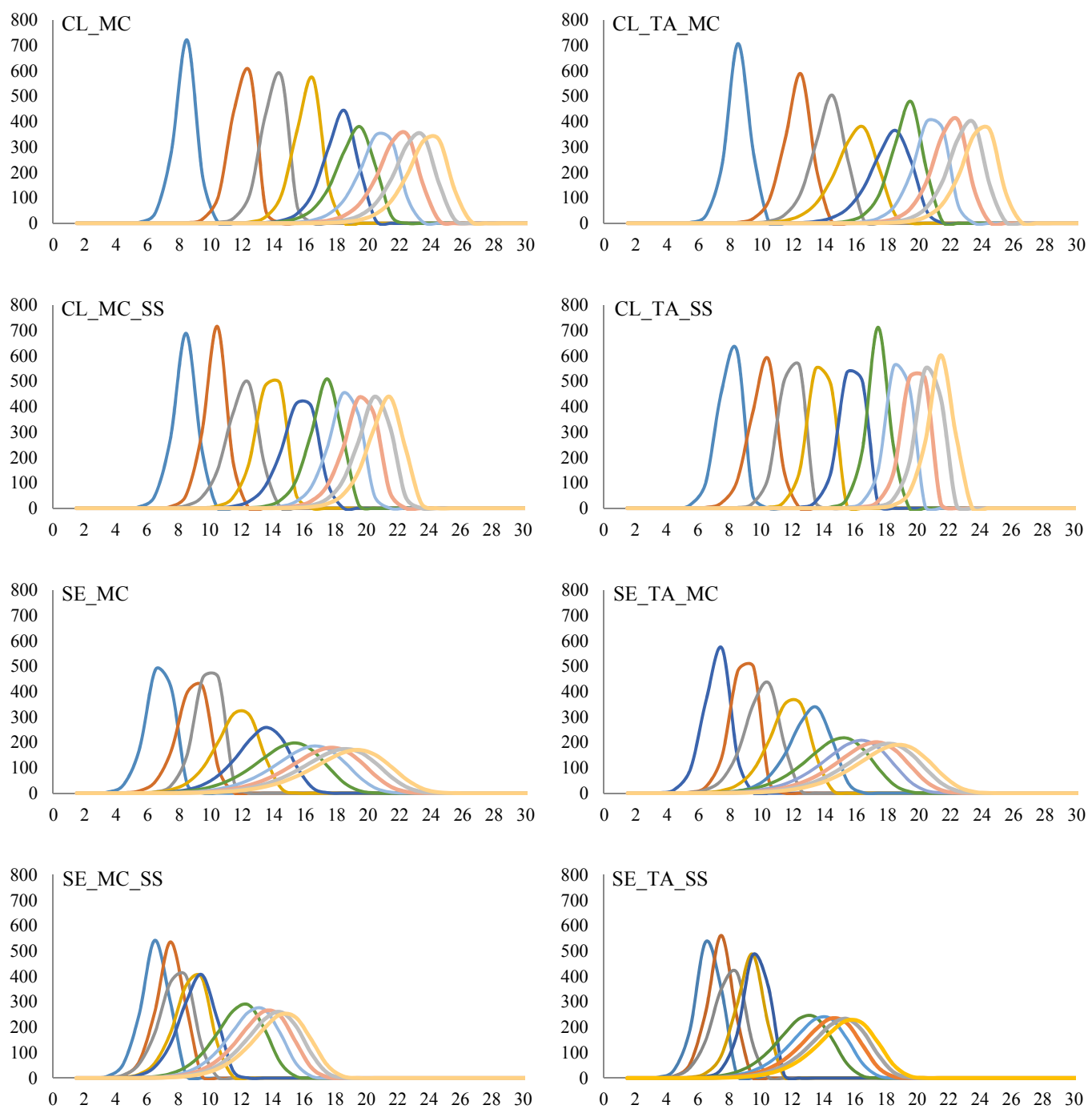

Figure 4. Evolution of the diameter distribution for different cultivation systems of Tectona grandis in the state of Mato Grosso, midwest Brazil

Note. $\mathrm{N}$ is the tree relative frequency and $\mathrm{CC}$ is the class center. Plot code codes stands for treatment composition such as: $\mathrm{CL}=$ clone; $\mathrm{SE}=$ Seed-origin; $\mathrm{MC}=$ Monoculture system; $\mathrm{TA}=$ Taungya system in the initial phase and $\mathrm{SS}=$ silvopastoral system.

Clonal plants in monoculture with silvipastoral system (CL_MC_SS), taungya and monoculture (CL_TA_MC) and monoculture (CL_MC) showed similar diameter distribution curves along the rotation. At the age of 27 months the diameters were distributed in six classes and in the last age evaluated (96 months) in nine classes, with the last diameter classes with the presence of individuals being $21 \mathrm{~cm}, 22 \mathrm{~cm}$ and $23 \mathrm{~cm}$, respectively. In the first treatment, the diameter class with the largest number of individuals (39\%) was 19, while in the other treatments it was class 21 , also with $39 \%$ of the individuals. Among the clonal tree, those in taungya and silvipastoral systems (CL_TA_SS) presented a different pattern of growth, with the distribution remaining in six classes. In this treatment, at the age of 96 months, there were $56 \%$ of individuals in the class $19 \mathrm{~cm}$, with no individuals above the class $20 \mathrm{~cm}$.

The seed-origin trees in taungya and silvipastoral systems (SE_TA_SS) and taungya and monoculture (SE_TA_MC) showed similar behavior. The distribution started in eight and six classes, respectively, ending with 13 and 12 classes at the age of 96 month, with $22 \%$ and $24 \%$ of the individuals present in the classes $14 \mathrm{~cm}$ and $13 \mathrm{~cm}$ and the last classes with presence of individuals were $18 \mathrm{~cm}$ and $17 \mathrm{~cm}$. The seed-origin trees in monoculture (SE_MC) and taungya (SE_TA_MC) also showed similarities. The distribution in these systems started with six and seven classes, later evolving to 15 and 16 classes at the age of 96 months, with $18 \%$ and $17 \%$ 
of the individuals present in the classes $16 \mathrm{~cm}$ and $17 \mathrm{~cm}$ and the last classes with presence of individuals were $21 \mathrm{~cm}$ and $22 \mathrm{~cm}$.

Figure 4 also shows that for the systems with clonal plants (CL_MC_SS, CL_TA_MC and CL_MC), from the age of 72 months onwards, there was a reduction in ingrowth in successive diameter classes, which indicates an upcoming stagnation phase. However, these plants in the taungya and silvipastoral system (CL_TA_SS) presented a tendency of stagnation from the 84 months of age. Similar results were also observed for seed-oring trees in monoculture (SE_MC and SE_TA_MC), however, with a flatter shape and individuals distributed in a larger number of diameter classes. In the treatments with the influence of brachiaria grass (SE_SS and SE_TA_SS), the ingrowth in successive diameter classes were quite irregular.

In these treatments, there was an infestation of Maconellicoccus hirsutus at 48 months, followed by a stagnation of growth up to 72 months, with a significant growth recovery in the following year with a trend of stagnation after 96 months. The effect on growth was likely due to the decrease of the leaf area, incidence of fumagina, die-back and sap suction. In the other treatments involving seed-origin plants, the effect was less pronounced. In clonal plants, which were also attacked, growth was less affected.

\subsection{Techinal Age of Thinninge}

The expolinear model was logical and presented biological realism in determining the technical age of the first thinning. Only the equations of the treatments involving seed-origin trees in silvopastoral system had a correlation coefficient below $90 \%$ (Table 5).

Table 5. Fitted expo-linear equations to estimate to mean percent ingrowth (MPI) as a function of age (A) and to determine technical age of thinning (TAT) for different cultivation system of Tectona grandis in the state of Mato Grosso, midwest Brazil

\begin{tabular}{llll}
\hline Treatment $^{1}$ & Equation $^{2}$ & Syx $^{\mathbf{3}}$ & $\mathbf{R y}^{\mathbf{4}}$ \\
\hline CL_MC & MPI $=\left(\frac{-0.051824}{-0.053345}\right) \operatorname{Ln}\{1+\exp [-0.053345(\mathrm{~A}-79.900859)]\}$ & 3.77 & 94.26 \\
CL_TA_MC & MPI $=\left(\frac{-0.049480}{-0.051981}\right) \operatorname{Ln}\{1+\exp [-0.051981(\mathrm{~A}-79.630728)]\}$ & 3.80 & 93.39 \\
CL_MC_SS & MPI $=\left(\frac{-0.037595}{-0.042091}\right) \operatorname{Ln}\{1+\exp [-0.042091(\mathrm{~A}-84.751355)]\}$ & 2.08 & 95.08 \\
CL_TA_SS & MPI $=\left(\frac{-0.033158}{-0.031946}\right) \operatorname{Ln}\{1+\exp [-0.031946(\mathrm{~A}-90.469292)]\}$ & 2.90 & 92.53 \\
SE_MC & MPI $=\left(\frac{-0.033778}{-0.061397}\right) \operatorname{Ln}\{1+\exp [-0.061397(\mathrm{~A}-84.161640)]\}$ & 3.20 & 91.24 \\
SE_TA_MC & MPI $=\left(\frac{-0.033069}{-0.061156}\right) \operatorname{Ln}\{1+\exp [-0.061156(\mathrm{~A}-84.508606)]\}$ & 3.25 & 90.97 \\
SE_MC_SS & MPI $=\left(\frac{-0.011853}{-0.091949^{2}}\right) \operatorname{Ln}\left\{1+\exp \left[-0.091949^{*}(\mathrm{~A}-113.756396)\right]\right\}$ & 4.54 & 63.60 \\
SE_TA_SS & MPI $=\left(\frac{-0.012739}{-0.145181^{2}}\right) \operatorname{Ln}\left\{1+\exp \left[-0.145181^{*}(\mathrm{~A}-115.293174)\right]\right\}$ & 5.62 & 61.52 \\
\hline
\end{tabular}

Note. ${ }^{1}$ Codes stands for treatment composition such as: $\mathrm{CL}=$ clone; $\mathrm{SE}=$ Seed-origin; $\mathrm{MC}=$ Monoculture system; TA = Taungya system in the initial phase and $\mathrm{SS}=$ silvopastoral system. ${ }^{2}$ All coefficients were significant in the $t$ test $\mathrm{t} 5 \%$ significance level, unless they are marked with "*”. ${ }^{3}$ residual standard error. ${ }^{4}$ Pearson correlation coefficient between the estimated and observed tree values.

In this study, the growth of clonal trees in systems with a final monoculture phase (CL_MC and CL_TA_MC) stagnated at 6.6 years; in monoculture and silvipastoral system (CL_MC_SS) at 7 years; and in taungya and silvipastoral (CL_TA_SS) 7.5 years. Seed-origin trees in systems with a final monoculture phase (SE_MC and SE_TA_MC) stagnated at 7 years, whereas those in taungya and silvipastoral (SE_TA_SS) and monoculture and silvipastoral (SE_MC_SS) systems stagnated at 9.4 and 9.6 years.

In general, clonal trees under monoculture presented the earliest growth stagnation, which can be explained by the faster growth of clonal trees associated with no competition with brachiaria grass. Clonal trees in systems with a silvopastoral phase and seed-origin in monoculture presented similar stagnation ages. These results evidence the high competition effect of brachiaria grass over teak trees (Figure 5). 

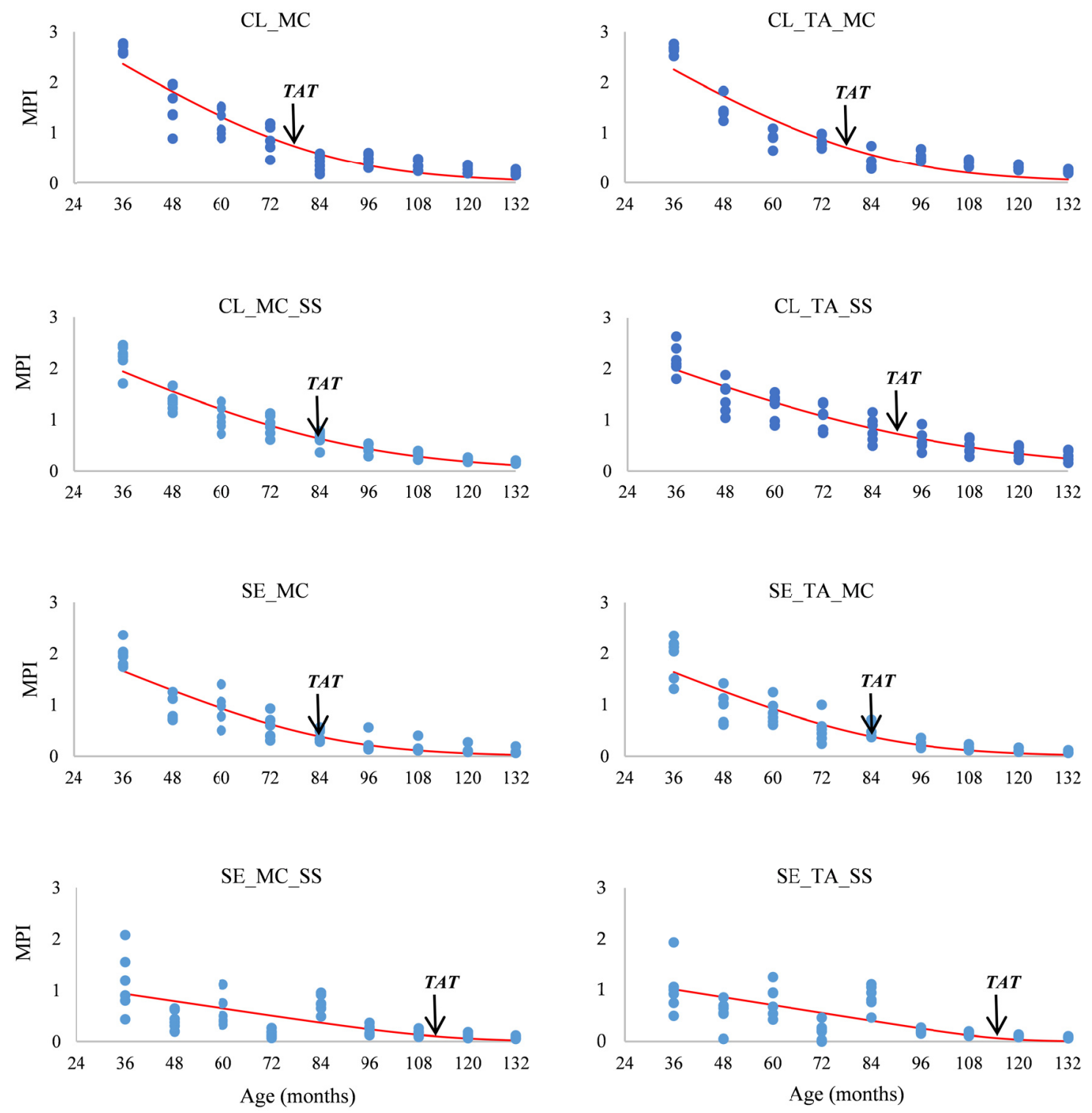

Figure 5. Technical age of thinning (TAT) for teak stands in different cultivation systems in the state of Mato Grosso, midwest Brazil

Note. ${ }^{1}$ Plot codes stands for treatment composition such as: $\mathrm{CL}=$ clone; $\mathrm{SE}=$ Seed-origin; $\mathrm{MC}=$ Monoculture system; $\mathrm{TA}=$ Taungya system in the initial phase and $\mathrm{SS}=$ silvopastoral system.

\section{Discussion}

We assessed the performance in terms of growth and structural development of clonal and seed-origin teak trees in different cultivation systems including monoculture and two agroforestry systems in the state of Mato Grosso, midwest Brazil. Clonal trees presented greater total height, diameter and basal area than seed-origin trees, independent of the system in which they were cultivated.

For example, in the monoculture system at 96 months of age, clonal plants (CL_MC) presented total height and diameter $24 \%$ higher than seed-origin trees (SE_MC). These results corroborate the findings in (Kaosa-Ard, Suangtho, \& Kjaer, 1998), which showed a genetic gain of the order of $20 \%$ with the selection of improved genotypes. Goh e Monteuuis (2012) found 30\% greater volume yield for clonal teak stands compared to stands composed by seed origin trees, at the age of 5 years.

These results evidence the gain in production and structural uniformity provided by the vegetative propagation of high productivity genotypes in comparison to seed-origin trees. Nevertheless, contrasting with the historical efforts made in the breeding and genetic improvement of Eucalyptus in Brazil (Gonçalves et al., 2013), there has 
been few initiatives focusing on these programs for teak (Costa et al., 2007; Schuhli \& Paludzyszyn Filho, 2010). This may be the reason for the high variability of productivity, low genetic diversity and the underexplored genetic potential of this species in Brazil (Alcântara \& Veasey, 2013; Costa \& Resende, 2001; Giustina et al., 2017; Shimizu, Klein, \& Oliveira, 2007).

Medeiros et al. (2015) pointed out that there is an increasing demand in quality and quantity of teak wood in the market, which will push more investments onto the implementation of tree improvement programs in order to produce superior genetic material for clonal propagation and also for improved seeds (Costa et al., 2015; Schuhli \& Paludzyszyn Filho, 2010). In addition, the interaction of trees with other plants in the system may also be governed by genetic characteristics, so that especial selection for deployment in agroforestry may be necessary. For example, assessing the effect of the weeds Urochloa decumbens (Stapf) R.D. Webster, Brachiaria plantaginea (Link) Hitchc., Brachiaria ruziziensis R. Germ. \& C.M. Evrard and Panicum maximum Jacq. on the initial growth of Eucalyptus urograndis clones, Pereira, Alves, \& Martins (2013) observed that negative effects of these plants on tree growth varied with genotype and pointed out the importance of site-specific genotype deployment.

In addition to propagation type effects, cultivation system had an effect and our results suggests that the consortium with grass (in the silvopastoral system phase) had a more negative effect on teak growth than the consortium with maize (in the agroforestry system phase). In the latter, Teak growth and consequently the technical age of thinning was little or not affected by maize. These results corroborate the hypothesis in Medeiros et al. (2015), which found that teak plants, whether clonal or seed-origin, in the taungya system grow initially slower, but tend to recover after the removal of the agricultural component.

The results obtained here demonstrate the technical feasibility of the taungya system, in which the main objective is to reduce the costs of implementation of the tree crop, since it takes advantage of the activities of maintenance of the agricultural crop and the revenues from the commercialization of its products (Rodrigues, Cullen Júnior, Moscogliato, \& Beltrame, 2008; Schlönvoigt \& Beer, 2001). In this same experimental area, Medeiros et al. (2015) verified that up to the age of 36 months there was a reduction of $21 \%$ and $27 \%$ in the cost of implantation and maintenance of the taungya system with clonal seed-origin trees, respectively, when compared to monocultures.

In addition to the silvicultural and economic analysis, it is necessary to consider that agroforestry systems, such as the taungya system, are essentially more sustainable when compared to monocultures (Menzies, 1988; Nair, 1985; Yeboah, 2016), since it seeks to optimize land use for agricultural, animal production and tree products (Alao \& Shuaibu, 2013). They also meet the precepts of environmental protection, especially those of tropical and subtropical regions (Sun et al., 2017) and products obtained in this type of system, especially those of animal origin, are becoming better preferred by consumers who have given greater importance to the provenance, production systems and animal welfare (Zanin et al., 2016).

The infestation of Maconellicoccus hirsutus (Silva et al., 2014) affected negatively the growth of teak trees, especially in the case of seed-origin trees in agroforestry and silvopastoral systems (SE_TA_SS and SE_SS), which showed lower resistance to the attack of this pest. In this experimental area, Silva et al. (2014) observed that the infestation occurred all along the stem to the upper part of the stem, with decreasing incidence from the base upwards. According to these authors, the highest concentration of this pest was found in cracks, pruning cicatrization callus and also in branches and lesions. In the crown, low infestation was detected in the lower and upper thirds and high infestation in the middle third (region with the highest volume of leaves), especially in the abaxial face, next to the leaf veins. The main symptoms observed by the authors were the death of young leaves, leaf area reduction, presence of fumagina on the adaxial side, dieback, leaf malformation, reduction in growth, necrosis and early yellowing of older leaves. Similar results were observed by Peres Filho, Ben-Dov, Wolff, Dorval, and Souza (2017) in commercial teak stands in the region where this experiment is located.

As mentioned, the integration of teak trees with forage crops, in this case brachiaria grass, influenced negatively the growth of the teak trees in terms of height and diameter when compared to the monoculture system (Figure 1), including in this case also an effect on the basal area and the ingrowth in successive diameter classes (Figure 4). This lower growth can be explained by the reduction of the growth rate (Table 2) due to the competition between the components (Domingos Júnior \& Coelho, 2018), restriction of the development of the root system (Schaller, Schroth, Beer, \& Jiménez, 2003) and possible direct and indirect allelopathic effects (Silva et al., 2017).

Although, we did not aim at assessing the forage production ( $U$. brizantha) as a function of sowing density, period of coexistence and distance of trees, studies with these objectives are recommended, since the competition 
with the trees can significantly reduce the production and the nutritional quality of the forage (Cabral et al., 2017), especially in crops with higher density of forage plants (Bacha, Pereira, Pires, Nepomuceno, \& Alves, 2016; Pereira, Souza, Silva, \& Martins, 2011).

The percentage entries method (PEM) (Garcia, 1999) was adequate to determine the technical age of the first thinning for teak stands in agroforestry systems, corroborating with results of Medeiros et al. (2017) and Nogueira et al. (2001). It was possible to identify the exact moment of change from the linear to the exponential phase (Figure 5), that is, the moment that the ingrowth in successive diameter classes was no longer significant, therefore, the beginning of growth stagnation and the moment of the thinning intervention.

The results obtained in this study indicated that the technical age of the first thinning was the earliest for clonal trees in monoculture followed by clonal trees in the other systems, then seed-origin trees in monoculture and, finally, seed-origin trees in agroforestry systems. The technical age of thinning observed hereby was compatible with that observed by Medeiros et al. (2017) in teak stands implanted in different spacings, in the municipality of Água Boa, also in the state of Mato Grosso, Brazil. For example, the authors found that in a $3.5 \mathrm{~m} \times 2.4 \mathrm{~m}$ planting spacing $\left(8.4 \mathrm{~m}^{2}\right.$ per plant), the TAT was at 78 months of age, similar to the result found in this study (79 months), with a spacing of $4 \times 2 \mathrm{~m}\left(8 \mathrm{~m}^{2}\right.$ per plant).

\section{Conclusions}

The clonal trees presented a better performance than the seed-origin trees.

Under the conditions studied, the taungya system did not affected negatively the growth of teak trees as compared to the monoculture.

The ingrowth in successive diameter classes decreases with age, regardless of the cropping system, and in agroforestry systems the decrease is less pronounced.

The diameters distribution projection model and percent entry method were efficient to monitor the growth and yield and to define the technical age of thinning of the tested cultivation system.

For the current type of management in the evaluated treatments, the technical age of the first thinning varied from 6 to 9 years.

\section{Acknowledgements}

We thank FAPEMAT (Foundation for the Support of Research in the state of Mato Grosso) for supporting this research in the form of the Research Support Funding Call n $n^{\circ}$.004/2009 - MASTER, the Federal Institue of the State of Mato Grosso-Campus Cacere- Prof. Olegário Baldo, and the Teak Resources Company (TRC).

The authors also thank the Municipal Government of Figueirópolis D’Oeste-MT, Brazil, Mr. Antônio Medeiros and family. We dedicate this work to Professor Carlos A. M. Passos (in memoriam).

\section{References}

Alao, J. S., \& Shuaibu, R. . (2013). Agroforestry practices and concepts in sustainable land use systems in Nigeria. Journal of Horticulture and Forestry, 5(10), 156-159. https://doi.org/10.5897/JHF11.055

Alcântara, B. K., \& Veasey, E. A. (2013). Genetic diversity of teak (Tectona grandis L.F.) from different provenances using microsatellite markers. Revista Árvore, 37(4), 747-758. https://doi.org/10.1590/S010067622013000400018

Alvares, C. A., Stape, J. L., Sentelhas, P. C., Gonçalves, J. L. de M., \& Sparovek, G. (2013). Köppen's climate classification map for Brazil. Meteorologische Zeitschrift, 22(6), 711-728. https://doi.org/10.1127/09412948/2013/0507

Bacha, A. L., Pereira, F. C. M., Pires, R. N., Nepomuceno, M. P., \& Alves, P. L. da C. A. (2016). Interference of seeding and regrowth of signalgrass weed (Urochloa decumbens) during the initial development of Eucalyptus urograndis (E. grandis $\times$ E. urophylla). Australian Journal of Crop Science, 10(3), 322-330. https://doi.org/10.21475/ajcs.2016.10.03.p6995

Cabral, C. E. A., Barros, L. V. de, Abreu, J. G. de, Silva, F. G. da, Cabral, C. H. A., Behling Neto, A., ... Dellarmelinda, T. M. M. (2017). Marandu palisade grass intercropped with densely spaced teak in silvopastoral system. Semina: Ciências Agrárias, 38(4), 2075. https://doi.org/10.5433/1679-0359.2017v38 n4p2075

Camino, R. de, \& Aymerich, J. P. M. (2013). La teca en América Latina. In Las plantaciones de teca en América Latina: Mitos y realidades (pp. 29-41). Turrialba: CATIE/FAO. 
Camino, R. de, \& Morales, J. P. (2013). Las plantaciones de teca en América Latina: Mitos y realidades. Serie Técnica. Informe técnico/CATIE. Turrialba: CATIE/FAO.

Cañadas-L., Á., Andrade-Candell, J., Domínguez-A., J., Molina-H., C., Schnabel-D., O., Vargas-Hernández, J., \& Wehenkel, C. (2018). Growth and Yield Models for Teak Planted as Living Fences in Coastal Ecuador. Forests, 9(2), 55. https://doi.org/10.3390/f9020055

Costa, R. B. da, Martinez, D. T., Chichorro, J. F., Bauer, M. de O., Cezana, D. P., \& Souza, T. R. de. (2015). Desempenho de progênies no pré-melhoramento de Tectona grandis L. f no Estado do Espírito Santo. Scientia Forestalis, 43(105), 211-216.

Costa, R. B. da, \& Resende, M. D. V. de. (2001). Melhoramento de espécies alternativas para o Centro Oeste-Teca. In M. D. V. de Resende (Ed.), Workshop sobre melhoramento de espécies florestais e palmáceas no Brasil (pp. 153-167). Colombo-PR.

Costa, R. B. da, Resende, M. D. V. de, \& Silva, V. S. de M. (2007). Experimentação e seleção no melhoramento genético de teca (Tectona grandis L. f.). Floresta e Ambiente, 14(1), 76-92.

Domingos Júnior, F. A., \& Coelho, L. (2018). Effect of Brachiaria Grass on Vegetative Development of Teak. Floresta e Ambiente, 25(4), 1-6. https://doi.org/10.1590/2179-8087.012615

FAO. (2009). The Future of Teak and the High-Grade Tropical Hardwood Sector: Planted Forests and Trees. ONU, Roma.

FAO. (2015). Report of the First Session of the FAO Panel of experts on Forest Gene Resources.

Fernández-Moya, J., Alvarado, A., Mata, R., Thiele, H., Segura, J. M., Vaides, E., ... Marchamalo-Sacristán, M. (2015). Soil fertility characterisation of teak (Tectona grandis L.f.) plantations in Central America. Soil Research, 53(4), 423. https://doi.org/10.1071/SR14256

Garcia, S. L. R. (1999). Ingresso Percentil: Teoria e aplicações em ciência florestal. Não Publicado, Viçosa, MG.

Giustina, L. Della, Rossi, A. A. B., Vieira, F. S., Tardin, F. D., Neves, L. G., \& Pereira, T. N. S. (2017). Variabilidade genética em genótipos de teca (Tectona grandis Linn. F.) baseada em marcadores moleculares ISSR e caracteres morfológicos. Ciencia Florestal, 27(4), 1311-1324. https://doi.org/10.5902/19805098 29894

Goh, D. K. S., \& Monteuuis, O. (2012). Behaviour of the "YSG Biotech TG1-8" teak clones under various site conditions: First observations. Bois et Forets Des Tropiques, 66(311), 5-19.

Golfari, L., Caser, R. L., \& Moura, V. P. G. (1978). Zoneamento ecologico esquematico para reflorestamento no Brasil (2nd ed.). Belo Horizonte: PNUD/FAO/IBDF/PRODEPEF.

Gonçalves, J. L. de M., Alvares, C. A., Higa, A. R., Silva, L. D., Alfenas, A. C., Stahl, J., ... Epron, D. (2013). Integrating genetic and silvicultural strategies to minimize abiotic and biotic constraints in Brazilian eucalypt plantations. Forest Ecology and Management, 301, 6-27. https://doi.org/10.1016/j.foreco.2012. 12.030

IBÁ (Brazilian Tree Industry). (2017). Relatório 2017. Indústria Brasileira de Árvores. Retrieved from http://iba.org/images/shared/ Biblioteca/IBA_RelatorioAnual2017.pdf

IMEA (Matogrossense Institute of Agropecuária). (2016). Expand planted forests in open areas. Retrieved August 23, 2018, from http://www. pcimonitor.org

Kaosa-ard, A. (1995). Management of Teak Plantations: Overview of problems in teak plantation establishment. Teak for the Future. Yangon, Myanmar: TEAKNET/FAO.

Kaosa-Ard, A., Suangtho, V., \& Kjaer, E. D. G. (1998). Genetic improvement of teak (Tectona grandis) in Thailand. Forest Genetic Resources, 26, 21-29.

Leite, H. G., Nogueira, G. S., Campos, J. C. C., Takizawa, F. H., \& Rodrigues, F. L. (2006). Um modelo de distribuição diamétrica para povoamentos de Tectona grandis submetidos a desbaste. Revista Árvore, 30(1), 89-98. https://doi.org/10.1590/S0100-67622006000100011

Leite, H. G., \& Tavares de Oliveira, F. H. (2002). Statistical procedure to test identity between analytical methods. Communications in Soil Science and Plant Analysis, 33(7-8), 1105-1118. https://doi.org/10.1081/ CSS120003875 
Medeiros, R. A. (2016). Potencial produtivo, manejo e experimentação em povoamentos de Tectona grandis L.f. no Estado de Mato Grosso. Universidade Federal de Viçosa, Minas Gerais, Brazil. Retrieved from http://www.locus.ufv.br/handle/123456789/9296

Medeiros, R. A., Paiva, H. N. de, Leite, H. G., Salles, T. T., Araújo Júnior, C. A., \& Dávila, F. S. (2017). Idade técnica do primeiro desbaste de povoamentos de teca em diferentes espaçamentos. Scientia Forestalis, 45(116), 705-716. https://doi.org/10.18671/scifor.v45n116.11

Medeiros, R. A., Paiva, H. N., Leite, H. G., Oliveira Neto, S. N., Vendrúscolo, D. G. S., \& Silva, F. T. (2015). Análise silvicultural e econômica de plantios clonais e seminais de Tectona grandis L.f. em sistema taungya. Revista Arvore, 39(5), 893-903. https://doi.org/10.1590/0100-67622015000500012

Menzies, N. (1988). Three hundred years of Taungya: A sustainable system of forestry in south China. Human Ecology, 16(4), 361-376. https://doi.org/10.1007/BF00891648

Midgley, S., Somaiya, R. T., Stevens, P. R., Brown, A., Kien, N. D., \& Laity, R. (2015). Planted teak: Global production and markets, with reference to Solomon Islands (Vol. 85). Canberra: Australian Centre for International Agricultural Research (ACIAR).

Moretti, M. S., Tsukamoto Filho, A. D. A., Costa, R. B. da, Neto, R. M. R., Medeiros, R. A., \& Sousa, R. A. T. de M. (2014). Crescimento inicial de plantas de teca em monocultivo e sistema Taungya com milho em Figueiropolis D’Oeste, Estado de Mato Grosso. Scientia Forestalis/Forest Sciences, 42(102), 269-277.

Nair, P. K. R. (1985). Classification of agroforestry systems. Agroforestry Systems, 3(2), 97-128. https://doi.org/ 10.1007/BF00122638

Neuroforest. (2012). FitFD—Sistema para ajuste de funções densidade de probabilidade. Retrieved from http://neuroforest.ucoz.com

Nogueira, G. S., Leite, H. G., Campos, J. C. C., Souza, A. L. de, \& Couto, L. (2001). Determinação da idade técnica de desbaste em plantações de eucalipto utilizando o método dos ingressos percentuais. Scientia Forestalis, 59, 51-59.

Nogueira, G. S., Leite, H. G., Campos, J. C. C., Takizawa, F. H., \& Couto, L. (2006). Avaliação de um modelo de distribuição diamétrica ajustado para povoamentos de Tectona grandis submetidos a desbaste. Revista Árvore, 30(3), 377-387. https://doi.org/10.1590/S0100-67622006000300008

Pandey, D., \& Brown, C. (2000). Teak: A global overview. Unasylva, 51(201), 3-13.

Pelissari, A. L., Caldeira, S. F., \& Drescher, R. (2013). Desenvolvimento Quantitativo e Qualitativo de Tectona grandis L.f. em Mato Grosso. Floresta e Ambiente, 20(3), 371-383. https://doi.org/10.4322/floram.2013. 027

Pelissari, A. L., Caldeira, S. F., Santos, V. S. dos, \& Santos, J. O. P. Dos. (2012). Correlação espacial dos atributos químicos do solo com o desenvolvimento da teca em Mato Grosso. Pesquisa Florestal Brasileira, 32(71), 247-256. https://doi.org/10.4336/2012.pfb.32.71.247

Pereira, F. C. M., Alves, P. L. da C. A., \& Martins, J. V. F. (2013). Interference of Grasses on the Growth of Eucalyptus Clones. Journal of Agricultural Science, 5(11), 173-180. https://doi.org/10.5539/jas.v5n11p173

Pereira, M. R. R., Souza, G. S. F., Silva, J. I. C., \& Martins, D. (2011). Densidades de plantas de Urochloa decumbens em convivência com Corymbia citriodora. Semina: Ciências Agrárias, 32(Suppl.), $1803-1812$. https://doi.org/10.5433/1679-0359.2011v32Suplp1803

Peres Filho, O., Ben-Dov, Y., Wolff, V. R. dos S., Dorval, A., \& Souza, M. D. de. (2017). Maconellicoccus hirsutus (Green) Register in Teak Forest Santds in the Mato Grosso State, Brazil. Floresta e Ambiente, 24. https://doi.org/10.1590/2179-8087.015715

Pérez, D., \& Kanninen, M. (2005). Stand growth scenarios for Tectona grandis plantations in Costa Rica. Forest Ecology and Management, 210(1-3), 425-441. https://doi.org/10.1016/j.foreco.2005.02.037

Regazzi, A. J., \& Silva, C. H. O. (2010). Testes para verificar a igualdade de parâmetros e a identidade de modelos de regressão não-linear em dados de experimento com delineamento em blocos casualizados. Revista Ceres, 57(3), 315-320. https://doi.org/10.1590/S0034-737X2010000300005

Rodrigues, E. R., Cullen Júnior, L., Moscogliato, A. V., \& Beltrame, T. P. (2008). O uso do sistema agroflorestal taungya na restauração de reservas legais: Indicadores econômicos. Floresta, 38(3), 517-525. https://doi.org/10.5380/rf.v38i3.12420 
Santos, H. G. dos, Jacomine, P. K. T., Anjos, L. H. C. dos, Oliveira, V. A. de, Lumbreras, J. F., Coelho, M. R., ... Cunha, T. J. F. (2013). Sistema brasileiro de classificação de solos (3 ed. rev., Vol. 1, p. 353). Rio de Janeiro: Embrapa Solos.

Schaller, M., Schroth, G., Beer, J., \& Jiménez, F. (2003). Root interactions between young Eucalyptus deglupta trees and competitive grass species in contour strips. Forest Ecology and Management, 179(1-3), 429-440. https://doi.org/10.1016/S0378-1127(02)00534-0

Schlönvoigt, A., \& Beer, J. (2001). Initial growth of pioneer timber tree species in a Taungya system in the humid lowlands of Costa Rica. Agroforestry Systems, 51(2), 97-108. https://doi.org/10.1023/A:101067 4402907

Schuhli, G. S. e, \& Paludzyszyn Filho, E. (2010). O cenário nacional da silvicultura de teca (Tectona grandis L. f.) e perspectivas de melhoramento. Pesquisa Florestal Brasileira, 30(63), 217-230. https://doi.org/10. 4336/2010pfb30.63.217

Shimizu, J. Y., Klein, H., \& Oliveira, J. R. V. de. (2007). Diagnóstico das Plantações Florestais em Mato Grosso (1st ed.). Cuiabá, MT: Central de Texto. Retrieved from http://www.arefloresta.org.br/uploads/downloads/ 0001522012113335.pdf

Silva, F. T. da, Rocha, J. R. M. da, Vendruscolo, D. G. S., Medeiros, R. A., Cedeño, P. E. L., \& Anjos, N. dos. (2014). Ocorrência de cochonilhas em Tectona grandis L.f., no Brasil (Vol. 1). XXV Congresso Brasileiro de Entomologia. Goiânia, Goiás, Brazil.

Silva, L. M. I. da, Silva, M. J. da, Rocha, J. S., Bianchini, E., Pimenta, J. A., Stolf-Moreira, R., \& Oliveira, H. C. (2017). Potential allelopathic effect of Brachiaria decumbens root exudates on neotropical tree seedlings. Theoretical and Experimental Plant Physiology, 29(4), 177-186. https://doi.org/10.1007/s40626-0170093-y

StatSoft. (2014). STATISTICA (Data analysis software system). Retrieved from http://www.statsoft.com

Sun, Y., Cao, F., Wei, X., Welham, C., Chen, L., Pelz, D., ... Liu, H. (2017). An Ecologically Based System for Sustainable Agroforestry in Sub-Tropical and Tropical Forests. Forests, 8(4), 102. https://doi.org/10.3390/ f8040102

Tonini, H., Costa, M. C. G., \& Scwengber, L. A. M. (2009). Crescimento da Teca (Tectona grandis) em Reflorestamento na Amazônia Setentrional. Pesquisa Florestal Brasileira, 0(59), 5-14. https://doi.org/ 10.4336/2009.pfb.59.05

Ugulino, B., Latorraca, J. V. de F., \& Tomazello Filho, M. T. (2014). Tree-ring growth response of teak (Tectona grandis L.f.) to climatic variables in central-west region of Brazil. Scientia Forestalis/Forest Sciences, 42(104), 473-482.

Yeboah, B. (2016). Sustainability assessment of the modified taungya system in Dormaa district of Ghana: 15-years after implementation. Faculty of Science and Forestry. Retrieved from http://epublications.uef.fi/ pub/urn_nbn_fi_uef-20160941/urn_nbn_fi_uef-20160941.pdf

Zanin, E., Bichel, A., \& Mangilli, L. (2016). Bem-estar de vacas leiteiras em sistema silvipastoril. Pubvet, 10(5), 381-387. https://doi.org/10.22256/pubvet.v10n5.381-387

\section{Appendix A}

Table A1. Mean values for tree height (ht), diameter at $1.3 \mathrm{~m}(\mathrm{dbh})$, minimum diameter (dmin), maximum diameter (dmax), mean quadratic diameter $(\mathrm{q})$, basal area $(\mathrm{G})$ and number of tree $(\mathrm{N})$ in an experimente of cultivation system of Tectona grandis in the state of Mato Grosso, midwest Brazil

\begin{tabular}{lllllllllll}
\hline Treatment $^{1}$ & Age & ht & gama & beta & dmin & dap & dmax & q & G & N \\
\hline CL_MC & 27 & 6.2 & 10.87147 & 6.71606 & 4.5 & 6.0 & 7.2 & 6.1 & 3.6 & 1229 \\
CL_MC & 36 & 7.9 & 15.47767 & 8.62700 & 6.4 & 7.9 & 9.1 & 7.9 & 6.0 & 1219 \\
CL_MC & 48 & 10.7 & 20.14505 & 12.26723 & 9.6 & 11.4 & 12.8 & 11.5 & 12.6 & 1219 \\
CL_MC & 60 & 12.3 & 21.98445 & 14.28782 & 10.4 & 13.4 & 15.0 & 13.5 & 17.5 & 1229 \\
CL_MC & 72 & 13.7 & 22.64616 & 16.44166 & 13.1 & 15.4 & 17.1 & 15.5 & 21.4 & 1136 \\
CL_MC & 84 & 14.6 & 20.65337 & 18.54791 & 15.0 & 17.7 & 19.6 & 17.8 & 28.1 & 1136 \\
CL_MC & 96 & 15.2 & 18.36794 & 19.54294 & 15.4 & 18.4 & 20.7 & 18.5 & 30.6 & 1136 \\
CL_MC_SS & 27 & 6.5 & 10.74466 & 6.42298 & 3.9 & 5.7 & 6.9 & 5.7 & 3.3 & 1250 \\
\hline
\end{tabular}




\begin{tabular}{|c|c|c|c|c|c|c|c|c|c|c|}
\hline CL_MC_SS & 36 & 8.0 & 14.49445 & 8.68617 & 6.5 & 7.9 & 9.4 & 7.9 & 6.3 & 1250 \\
\hline CL_MC_SS & 48 & 10.1 & 18.46319 & 10.61717 & 8.0 & 9.8 & 11.9 & 9.9 & 9.7 & 1250 \\
\hline CL_MC_SS & 60 & 11.7 & 14.30250 & 12.40016 & 9.1 & 11.5 & 13.8 & 11.6 & 13.3 & 1250 \\
\hline CL_MC_SS & 72 & 13.4 & 19.09271 & 14.13812 & 10.8 & 13.4 & 15.7 & 13.4 & 17.9 & 1250 \\
\hline CL_MC_SS & 84 & 14.8 & 16.52420 & 16.09758 & 12.4 & 15.4 & 18.0 & 15.4 & 23.6 & 1250 \\
\hline CL_MC_SS & 96 & 15.4 & 20.74632 & 17.68394 & 14.1 & 16.9 & 19.7 & 16.9 & 27.8 & 1229 \\
\hline CL_TA_MC & 27 & 6.2 & 10.19018 & 6.77252 & 4.7 & 6.2 & 7.9 & 6.3 & 3.8 & 1250 \\
\hline CL_TA_MC & 36 & 8.1 & 15.55277 & 8.75995 & 6.7 & 8.1 & 9.4 & 8.1 & 6.4 & 1250 \\
\hline CL_TA_MC & 48 & 11.0 & 17.25067 & 12.57616 & 10.1 & 11.7 & 13.2 & 11.8 & 13.6 & 1250 \\
\hline CL_TA_MC & 60 & 12.5 & 16.79427 & 14.59645 & 11.6 & 13.7 & 15.5 & 13.7 & 18.6 & 1250 \\
\hline CL_TA_MC & 72 & 14.2 & 14.00118 & 16.40892 & 12.9 & 15.3 & 17.6 & 15.4 & 21.7 & 1167 \\
\hline CL_TA_MC & 84 & 15.3 & 16.30590 & 18.62196 & 14.8 & 17.6 & 20.1 & 17.6 & 28.5 & 1167 \\
\hline CL_TA_MC & 96 & 15.6 & 22.99173 & 19.53924 & 15.5 & 18.5 & 21.4 & 18.6 & 31.0 & 1146 \\
\hline CL_TA_SS & 27 & 5.7 & 11.76213 & 6.72449 & 4.2 & 5.9 & 7.0 & 5.9 & 3.5 & 1240 \\
\hline CL_TA_SS & 36 & 7.7 & 13.96264 & 8.28677 & 5.9 & 7.5 & 8.5 & 7.5 & 5.5 & 1240 \\
\hline CL_TA_SS & 48 & 10.0 & 14.73257 & 10.45039 & 7.3 & 9.5 & 11.0 & 9.6 & 8.9 & 1229 \\
\hline CL_TA_SS & 60 & 11.3 & 20.44962 & 12.17634 & 8.5 & 11.2 & 12.7 & 11.2 & 12.1 & 1219 \\
\hline CL_TA_SS & 72 & 12.6 & 23.63680 & 14.06344 & 9.9 & 13.1 & 14.8 & 13.1 & 16.5 & 1219 \\
\hline CL_TA_SS & 84 & 14.5 & 26.84796 & 16.08947 & 11.4 & 15.0 & 16.9 & 15.0 & 21.7 & 1219 \\
\hline CL_TA_SS & 96 & 15.1 & 32.87815 & 17.73270 & 12.7 & 16.7 & 18.8 & 16.7 & 26.8 & 1219 \\
\hline SE_MC & 27 & 4.9 & 12.34737 & 5.87089 & 3.1 & 5.1 & 6.5 & 5.2 & 2.5 & 1157 \\
\hline SE_MC & 36 & 6.8 & 9.71435 & 7.04018 & 4.3 & 6.2 & 7.9 & 6.2 & 3.6 & 1136 \\
\hline SE_MC & 48 & 8.5 & 10.79906 & 9.19724 & 6.0 & 8.3 & 10.0 & 8.3 & 6.2 & 1136 \\
\hline SE_MC & 60 & 9.4 & 14.52750 & 10.12787 & 6.8 & 9.3 & 11.4 & 9.4 & 8.0 & 1136 \\
\hline SE_MC & 72 & 10.4 & 9.84746 & 12.12043 & 7.5 & 11.0 & 13.8 & 11.1 & 10.4 & 1063 \\
\hline SE_MC & 84 & 11.0 & 9.23699 & 13.79253 & 8.5 & 12.5 & 15.7 & 12.6 & 13.4 & 1063 \\
\hline SE_MC & 96 & 11.4 & 7.90416 & 15.61315 & 8.1 & 14.0 & 18.8 & 14.3 & 16.9 & 1052 \\
\hline SE_MC_SS & 27 & 4.8 & 8.36294 & 5.69099 & 2.6 & 4.9 & 6.5 & 5.0 & 2.4 & 1167 \\
\hline SE_MC_SS & 36 & 6.5 & 9.34109 & 6.79320 & 4.2 & 6.0 & 7.4 & 6.1 & 3.4 & 1167 \\
\hline SE_MC_SS & 48 & 7.5 & 10.47399 & 7.76040 & 5.1 & 6.9 & 9.0 & 7.0 & 4.6 & 1157 \\
\hline SE_MC_SS & 60 & 8.3 & 8.77311 & 8.23725 & 5.3 & 7.5 & 9.9 & 7.6 & 5.3 & 1157 \\
\hline SE_MC_SS & 72 & 8.7 & 9.56610 & 9.25234 & 5.8 & 8.5 & 11.5 & 8.6 & 6.8 & 1157 \\
\hline SE_MC_SS & 84 & 9.4 & 9.47213 & 9.58454 & 6.0 & 8.8 & 12.0 & 9.0 & 7.4 & 1157 \\
\hline SE_MC_SS & 96 & 10.5 & 8.63203 & 12.42006 & 6.9 & 11.4 & 15.7 & 11.6 & 12.3 & 1157 \\
\hline SE_TA_MC & 27 & 5.3 & 11.35174 & 5.86091 & 3.6 & 5.3 & 6.9 & 5.4 & 2.7 & 1188 \\
\hline SE_TA_MC & 36 & 7.2 & 10.67815 & 7.43424 & 4.9 & 6.6 & 8.1 & 6.7 & 4.2 & 1198 \\
\hline SE_TA_MC & 48 & 8.8 & 13.57332 & 9.14644 & 6.0 & 8.5 & 10.6 & 8.5 & 6.9 & 1209 \\
\hline SE_TA_MC & 60 & 9.6 & 10.69479 & 10.38790 & 6.8 & 9.5 & 12.2 & 9.6 & 8.8 & 1209 \\
\hline SE_TA_MC & 72 & 10.7 & 10.72222 & 12.15251 & 8.0 & 11.2 & 14.5 & 11.3 & 11.2 & 1125 \\
\hline SE_TA_MC & 84 & 11.1 & 11.33772 & 13.50110 & 9.1 & 12.6 & 16.3 & 12.7 & 14.3 & 1125 \\
\hline SE_TA_MC & 96 & 11.8 & 8.15619 & 15.43955 & 8.9 & 14.1 & 18.5 & 14.4 & 18.2 & 1125 \\
\hline SE_TA_SS & 27 & 4.7 & 9.32492 & 6.25311 & 3.3 & 5.3 & 7.0 & 5.4 & 2.7 & 1125 \\
\hline SE_TA_SS & 36 & 6.6 & 10.47883 & 6.91629 & 4.0 & 6.0 & 7.1 & 6.0 & 3.2 & 1125 \\
\hline SE_TA_SS & 48 & 7.7 & 11.36030 & 7.70132 & 5.1 & 6.8 & 8.4 & 6.9 & 4.1 & 1104 \\
\hline SE_TA_SS & 60 & 8.3 & 9.31888 & 8.32909 & 5.5 & 7.4 & 9.3 & 7.5 & 4.8 & 1104 \\
\hline SE_TA_SS & 72 & 8.8 & 12.21649 & 9.60957 & 6.4 & 8.6 & 10.6 & 8.7 & 6.3 & 1073 \\
\hline SE_TA_SS & 84 & 9.8 & 14.74220 & 9.96653 & 6.7 & 8.9 & 11.1 & 9.0 & 6.8 & 1073 \\
\hline SE_TA_SS & 96 & 10.7 & 8.42327 & 13.29267 & 8.1 & 11.8 & 15.2 & 12.0 & 12.1 & 1084 \\
\hline
\end{tabular}

Note. ${ }^{1}$ Codes stands for treatment composition such as: $\mathrm{CL}=$ clone; $\mathrm{SE}=$ Seed-origin; $\mathrm{MC}=$ Monoculture system; $\mathrm{TA}=$ Taungya system in the initial phase and $\mathrm{SS}=$ silvopastoral system.

\section{Copyrights}

Copyright for this article is retained by the author(s), with first publication rights granted to the journal.

This is an open-access article distributed under the terms and conditions of the Creative Commons Attribution license (http://creativecommons.org/licenses/by/4.0/). 